\title{
Survei Kemampuan Guru dan Orangtua dalam Stimulasi Dini Sensori pada Anak Usia Dini
}

\author{
R. Sri Martini Meilanie $e^{\bowtie}$ \\ Pendidikan Anak Usia Dini, Universitas Negeri Jakarta \\ DOI: $10.31004 /$ obsesi.v5i1.741
}

\begin{abstract}
Abstrak
Stimulasi dini sensori merupakan proses mengembangkan potensi anak melalui rangsangan yang mengaktifkan panca indera. Penelitian ini bertujuan untuk mengetahui kemampuan gurudan orangtua dalam memberikan stimulasi dini sensori pada anak kelompok usia 4-6 tahun. Penelitian menggunakan metode deskriptif kuantitatif dengan pendekatan survei. Tempat penelitian yaitu Pos Paud di lingkungan kecamatan Bekasi Utara. Responden dalam penelitian ini terdiri dari guru Pos Paud sejumlah 60 orang, responden orang tua sejumlah 25 orang, dan responden guru yang diwawancara 15 orang. Alat pengumpul data menggunakan angket dan wawancara. Analisa data menggunakan tendensi sentral dan teknik persentase. Hasil penelitian menunjukkan bahwa kemampuan guru Pos Paud dan orangtua di Kecamatan Bekasi Utara berada pada kategori"baik" dalam stimulasi dini sensori berbasis aktivitas dengan pancaindera pada anak usia 4-6 tahun. Hasil penelitian ini pun menyatakan bahwa peran guru dan orangtua dalam stimulasi dini sensori berpengaruh pada perkembangan anak kelompok usia 4-6 tahun.
\end{abstract}

Kata Kunci: stimulasi dini; sensori; aktivitas bermain panca indera.

\begin{abstract}
Sensory early stimulation is the process of developing children's potential through stimulation that activates the five senses. This study aims to determine the ability of teachers to provide sensory early stimulation to children aged 4-6 years. This research uses descriptive quantitative method with a survey approach. The place of research is Pos Paud in the district of North Bekasi. Respondents in this study consisted of 60 Pos Paud teachers, 25 old respondents, and 15 teachers interviewed. Data collection tools using questionnaires and interviews. Data analysis using central tendency and proportion technique. The results showed that the ability of Pos Paud teachers and parents in North Bekasi District was in the "good" category in sensory early stimulation based on sensory activity in children aged 4-6 years. The results of this study also state that the role of teachers and parents in sensory early stimulation affects the development of children aged 4-6 years.
\end{abstract}

Keywords: early stimulation; sensory; the activity of playing the five senses

Copyright (c) 2020 R. Sri Martini Meilanie

$\triangle$ Corresponding author:

Email Address : r.srimartini@gmail.com (Jakarta, Indonesia)

Received 1 September 2020, Accepted 15 September 2020, Published 17 September 2020 


\section{PENDAHULUAN}

Anak usia dini merupakan anak dalam rentang usia 0 hingga 6 tahun yang pada masa ini mereka berada pada perkembangan terpesatnya. Anak usia dini terlahir dengan jutaan potensi yang jika distimulasi akan berkembang menjadi berbagai kemampuan yang menjadi bekal mereka dalam menghadapi setiap tuntutan yang muncul dalam sepanjang kehidupan mereka. Optimalnya berbagai perkembangan potensi anak usia dini bergantung pada lingkungan dan orang dewasa di sekitar anak seperti orangtua dan guru pendidikan anak usia dini yang mengupayakan stimulasi berbagai potensi ini secara tepat. Oleh karena pentingnya stimulasi anak usia dini, maka kemampuan orangtua dan guru dalam melakukan berbagai stimulasi menjadi faktor penting dalam proses tumbuh kembang anak (Husain \& Kaharu, 2020). Berbicara tentang stimulasi, dari segi pengertian merupakan sebuah proses sesuai aturan yang diberikan pada anak sebagai bantuan dan merupakan keharusan bila ingin pertumbuhan dan perkembangan anak optimal (Mufarizuddin, 2017). Salah satu stimulasi yang perlu dilakukan pada anak usia dini adalah stimulasi yang berkaitan dengan sensori. Stimulasi sensori mengakomodir kebutuhan anak untuk mengeksplorasi lingkungan dan kreativitas anak (Zmigrod, Colzato, \& Hommel, 2015). Menurut Montessori, cara paling efektif untuk anak belajar dan mengembangkan potensinya adalah melalui kegiatan main sensori (Darnis, 2018). Setiap individu dilahirkan dengan kemampuan sensorik dasar yang akan mengalami perkembangan (Meggit, 2018). Sejak lahir anak membutuhkan bantuan indera yang digunakan untuk mengeksplorasi objek serta lingkungan sekitar melalui kegiatan seharihari. Fase anak pada masa bayi hingga usia tertentu mempergunakan sistem penginderaan/sensori dan aktivitas-aktivitas motorik untuk mengenal objek atau benda dan lingkungan sekitar diri anak (Putri, Sofia, \& Utaminingsih, 2017). Berdasarkan pernyataan dan pendapat ahli di atas, maka stimulasi dini sensori merupakan langkah stimulasi awal yang perlu dilakukan karena tahapan perkembangan anak usia dini yang efektif adalah melalui pengembangan sensori anak yang berdampak pada terpenuhinya kebutuhan anak dalam eksplorasi lingkungan.

Adapun dalam pelaksanaan stimulasi dini sensori pada anak usia dini, selain dilakukan orangtua perlu diteruskan oleh pengasuh anak, kelompok masyarakat, dan atau oleh pendidik di lembaga pendidikan anak usia dini di lingkungan sekitar anak. Hal ini atas dasar pemberian stimulasi pada anak harus dilakukan secara terus menerus dan berkelanjutan dengan rasa kasih sayang dan melalui konsep bermain dan permainan. Stimulasi dini yang dilakukan pun bertujuan untuk menumbuhkan potensi-potensi tersembunyi anak (Saipudin, 2010). Proses tumbuh kembang setiap anak bukan hanya memiliki aspek perkembangan seperti moral, fisik motorik, bahasa, motorik, sosial emosional, namun juga secara holistik anak memiliki kebutuhan kesehatan, pengasuhan, kenyamanan, pendidikan dan perlindungan (Yulianto, Lestariningrum, \& Utomo, 2016). Apabila stimulasi diberikan kepada anak sedini mungkin, terus-menerus, dan berkelanjutan maka hasil stimulasi akan bermanfaat bagi proses kesiapan dan kematangan serta berdampak pada keberhasilan anak menjalani kehidupannya. Stimulasi dini yang dilakukan oleh orang tua dan guru pun akan menumbuhkan kepercayaan diri dan kemandirian pada anak serta optimalnya capaian perkembangan anak (Astuti, Adiba, \& Muna, 2017). Sebaliknya jika pola stimulasi yang diterapkan tidak tepat akan berdampak pula pada kurangnya pengalaman yang diterima anak (Hasanah \& Sugito, 2020). Berdasarkan pernyataan tersebut, maka dalam pelaksanaan stimulasi dini sensori perlu dilakukan oleh semua orang dewasa di sekitar anak secara berkelanjutan, secara terpadu, serta sesuai tahapan perkembangan anak karena akan berdampak positif bagi tumbuh kembang anak.

Adapun terkait dengan stimulasi dini sensori anak, pada artikel (Niken, 2016) dinyatakan bahwa terdapat satu dari enam anak bisa mengalami masalah sensoris yang mempengaruhi aktivitas sehari-hari anak dengan tingkat masalah yang berbeda-beda setiap anaknya. Hal ini diperkuat dalam penelitian (Haryanti, Ashom, \& Aeni, 2019) bahwa angka kejadian gangguan perkembangan anak di dunia masih tergolong tinggi, salah satunya di 
Indonesia yaitu sebesar 13-18\%. Berdasarkan data tersebut maka dapat dikatakan bahwa masalah sensori dapat dialami oleh siapa saja, bukan saja oleh anak yang tergolong anak berkebutuhan khusus namun dapat dijumpai pada anak yang terlihat normal dikarenakan kurangnya pengalaman yang didapat selama masa tumbuh kembangnya. Selanjutnya dalam penelitian (Pratiwi, 2020) dinyatakan bahwa terjadinya peningkatan mulai dari 39\% hingga $80 \%$ anak pada masa kini yang banyak menghabiskan waktu dengan menggunakan perangkat elektronik atau gawai. Mengutip pernyataan Dr Miller bahwa perangkat elektronik telah menimbulkan fenomena bermain anak menjadi pasif sehingga informasi sensori dan stimulasi yang didapat anak menjadi terbatas yang akhirnya menjadi masalah sensori seperti gangguan motorik dan gangguan fokus (Andriani, 2017). Kondisi ini menjadi salah satu faktor keterbatasan input sensori pada anak yang kemudian menjadi hambatan hingga muncul masalah sensoris pada masa tumbuh kembang anak ditunjukkan dengan gejala perilaku dalam keseharian anak.

Berdasarkan uraian di atas, maka dalam penelitian ini fokus penelitian adalah melihat bagaimana kemampuan guru Pos Paud dan orangtua dalam stimulasi yang melibatkan panca indera, seperti sentuhan, penglihatan, pendengaran berbasis aktivitas bermain pada anak kelompok usia 4-6 tahun.

\section{METODOLOGI}

Penelitian ini dilakukan menggunakan metode deskriptif kuantitatif dengan pendekatan survei. Penelitian ini pun dilakukan untuk mengetahui gambaran utuh mengenai kemampuan guru dan orangtua terhadap stimulasi sensori anak berbasis aktivitas bermain dengan panca indera pada anak usia 4-6 tahun yang berada di Kecamatan Bekasi Utara. Berikut ini adalah gambaran desain penelitian untuk mengetahui kemampuan guru dan orangtua anak kelompok usia 4-6 tahun dalam stimulasi dini sensori berbasis aktivitas bermain dengan panca indera pada layanan Pos Paud di Kecamatan Bekasi Utara:

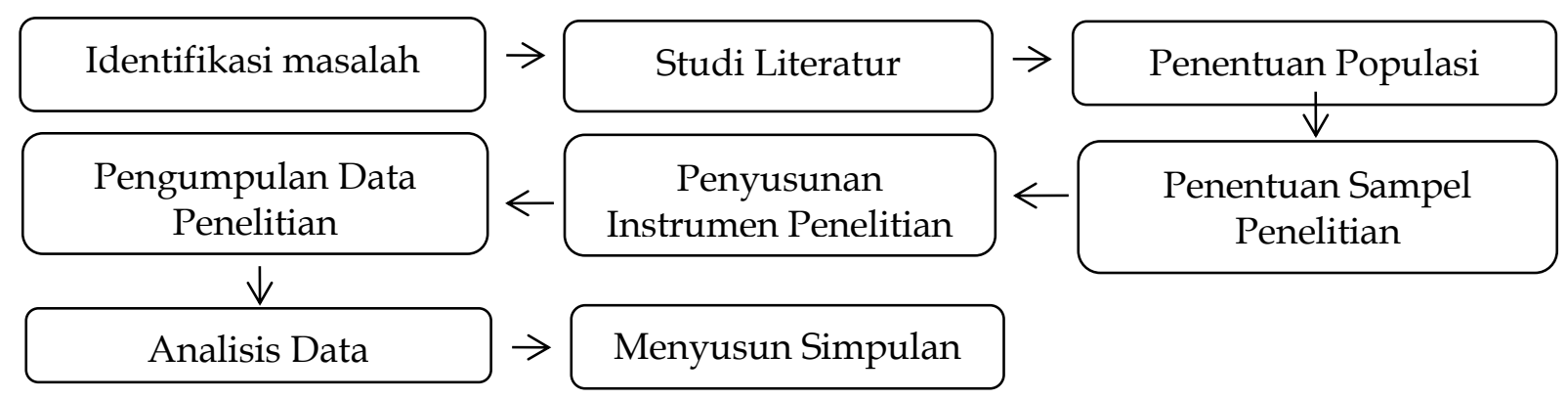

\section{Gambar 1. Desain Penelitian Analisis Kemampuan Guru dan Orangtua dalam Stimulasi Dini Sensori pada Anak Kelompok Usia 4-6 Tahun}

Adapun untuk sumber data penelitian di ambil dari populasi guru Pos Paud di kota Bekasi sebanyak 294 guru dengan sampel penelitian adalah 60 orang guru Pos Paud di kecamatan Bekasi Utara. Sedangkan responden orangtua yang memiliki anak usia 4-6 tahun diambil sampel sebanyak 25 orangtua. Selanjutnya, teknik sampling yang digunakan pada penelitian ini adalah dengan menggunakan Teknik purposive random sampling atau mengambil sampel secara acak kemudian didukung dengan melakukan pertimbangan. Teknik pengumpulan data dengan menggunakan angket yang berisi indikaotr kemampuan guru dan orangtua dalam stimulasi sensori dini pada anak kelompok usia 4-6 tahun berbasis aktivitas bermain dengan panca indera. Angket ini diedarkan pada bulan April-Juli 2020 melalui aplikasi google form yang tautannya disebarkan melalui grup whatsapp para guru dan orangtua. Adapun angket yang digunakan dalam penelitian ini berupa angket dengan menggunakan skala Likert, dimana skala Likert yang mengukur tarap kemampuan guru dan orangtua dalam melakukan stimulasi sensori dini pada anak kelompok usia 4-6 tahun. Data 
DOI: 10.31004/obsesi.v5i1.741

juga dilengkapi dengan wawancara mendalam melalui aplikasi voice whatsapp dan videocall hingga data yang diperlukan telah memenuhi kebutuhan penelitian. Selanjutnya, setelah data terkumpul dalam penelitian ini, dilakukan analisis data dengan teknik tendensi sentral dan persentase. Teknik persesentase tersebut digunakan untuk mengetahui besarnya persentase yang menunjukkan pada kategori tertentu dan menyatakan informasi mengenai kemampuan guru Pos Paud dan orangtua terhadap stimulasi dini sensori pada anak usia 4-6 tahun. Angka yang diperoleh dari penghitungan persentase merupakan besaran tingkatan kemampuan guru yang dijadikan responden dalam penelitian.

Tabel 1. Kisi-Kisi Instrumen Kemampuan Guru dan Orangtua dalam Stimulasi Dini Sensori

\begin{tabular}{|c|c|c|c|}
\hline $\begin{array}{c}\text { Aspek atau Ruang } \\
\text { Lingkup }\end{array}$ & Indikator & $\begin{array}{l}\text { Nomor Butir } \\
\text { Pernyataan }\end{array}$ & $\begin{array}{c}\text { Banyak } \\
\text { Butir }\end{array}$ \\
\hline $\begin{array}{l}\text { Pengetahuan guru } \\
\text { dan orangtua } \\
\text { tentang stimulasi } \\
\text { dini sensori }\end{array}$ & $\begin{array}{l}\text { Tujuan dan manfaat memberikan stimulasi } \\
\text { dini sensori anak } \\
\text { Dampak positif dan } \\
\text { Negatifdaripemberianstimulasidinisensorianak }\end{array}$ & $\begin{array}{l}1,2,3,4,5,6,7,8 \\
9,10,11\end{array}$ & 11 \\
\hline $\begin{array}{l}\text { Keterampilan guru } \\
\text { dan orang tua } \\
\text { dalam } \\
\text { Pemberian } \\
\text { stimulasi dini } \\
\text { sensori }\end{array}$ & $\begin{array}{l}\text { Keterampilan guru ketika anak bermain } \\
\text { dengan kegiatan melibatkan panca indera } \\
\text { (melihat, mendengar, meraba) }\end{array}$ & $\begin{array}{l}12,13,14,15,16 \\
17,18\end{array}$ & 7 \\
\hline Total & & 18 & \\
\hline
\end{tabular}

\section{HASIL DAN PEMBAHASAN}

Berdasarkan hasil survei yang dilakukan di Kecamatan Bekasi Utara mengenai kemampuan guru dan orangtua dalam stimulasi dini sensori anak berbasis aktivitas dengan panca indera pada anak kelompok usia 4-6 tahun memperoleh hasil penelitian secara umum yang menunjukkan bahwa kemampuan guru Pos Paud dan orangtua di Kecamatan Bekasi Utara berada dalam kategori "baik".

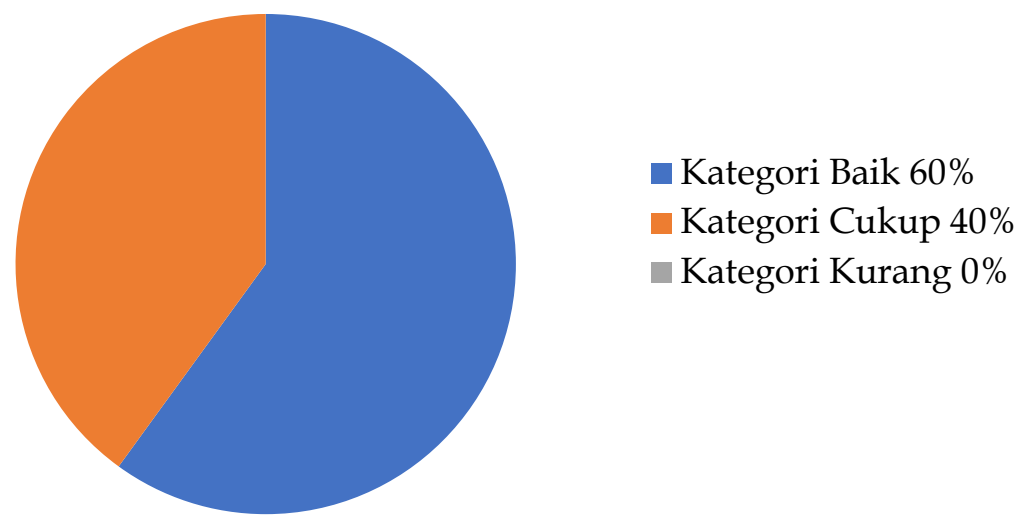

\section{Gambar 2. Grafik Pie kemampuan Guru Pos Paud}

Data yang terkumpul dari responden guru yang berada pada kategori "baik" sebanyak 36 orang atau $60 \%$ dari jumlah responden yang ada. Selanjutnya responden guru yang berada pada kategori "cukup" terdapat 24 orang atau 40\% dari keseluruhan responden guru dalam penelitian ini. Dalam penelitian ini tidak ada responden guru yang berada pada kategori "kurang". Berdasarkan data tersebut maka didapat data bahwa kemampuan guru Pos Paud terhadap stimulasi dini sensori anak berbasis aktivitas dengan panca indera pada anak usia 46 tahun di Kecamatan Bekasi Utara berada pada kategori “baik. Berdasarkan hasil survei 
tersebut dapat dikatakan bahwa guru telah dapat memahami pentingnya stimulasi dini sensori pada anak di Pos Paud. Hasil penelitian tersebut selaras dengan pendapat ahli bahwa guru pendidikan anak usia dini perlu memahami bahwa proses stimulasi di pendidikan anak usia dini diarahkan pada proses membantu perkembangan secara optimal salah satunya kekuatan sensori (Sasi \& Syafrudin, 2019). Penguasaan dan pemahaman tentang pentingnya stimulasi dini oleh guru ini merupakan salah satu indikator guru pendidikan anak usia dini yang profesional dimana guru menyadari betapa pentingnya memenuhi hak-hak anak untuk bertumbuh kembang secara optimal (Roza, Nurhafizah, \& Yaswinda, 2019).

Selain itu, berdasarkan hasil survei tersebut pun didapat gambaran bahwa guru telah memahami tentang stimulasi dini pada anak harus sesuai dengan tahapan atau fase anak saat ini yaitu berada pada masa bermain. Melalui bermain ketika stimulasi dini sensori, anak akan memperoleh pengalaman dan pemahaman sekaligus (Jumilah, Efastri, \& Fadillah, 2018). Pernyataan tersebut selaras dengan pandangan ahli (Lubis, 2019) yang menyatakan bahwa bermain adalah cara yang paling baik untuk mengembangkan anak, dengan bermain anak mampu memahami diri, orang lain, dan lingkungan. Papalia dan Feldman (Hewi \& Asnawati, 2020) mengemukakan bahwa bermain sebagai aktivitas anak usia dini memiliki andil terhadap aspek perkembangan anak usia dini. Melalui aktivitas bermain anak menguasai fungsi-fungsi tubuh dengan baik, mengkoordinasi antara mata dengan gerakannya, melatih otot-otot anak, membuat keputusan dan mendapatkan keahlian/kemampuan baru. Keseluruhan pendapat di atas diperkuat dalam penelitian (Putri et al., 2017) yang menyatakan bahwa salah satu bentuk bermain pada anak yang penting adalah anak bermain dengan melibatkan seluruh fisik anak untuk berhubungan langsung dengan lingkungan.

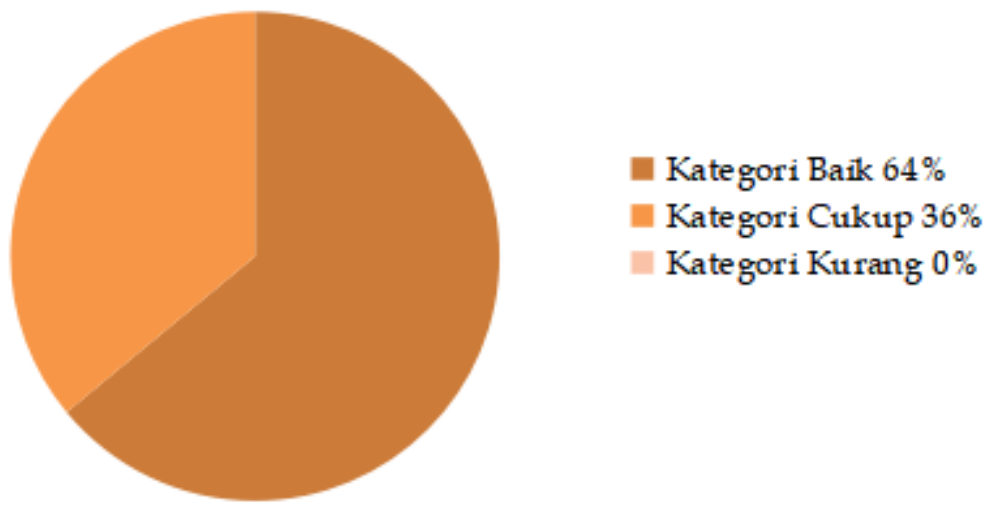

\section{Gambar 3. Grafik Pie Kemampuan Orangtua dalam Stimulasi Sensori Dini}

Selanjutnya dari data penelitian ini, responden orangtua berada pada kategori "baik" sebanyak 16 orang atau $64 \%$ dari jumlah responden yang ada. Selanjutnya responden yang berada pada kategori "cukup" terdapat 9 orang atau 36\% dari keseluruhan responden orangtua dalam penelitian ini. Dalam penelitian ini tidak ada responden orangtua yang berada pada kategori "kurang". Dengan demikian dapat dikatakan bahwa kemampuan orangtua terhadap stimulasi dini sensori anak berbasis aktivitas bermain dengan mengaktifkan panca indera pada anak usia 4-6 tahun di Kecamatan Bekasi Utara berada pada kategori "baik" juga. Hasil survei terhadap responden orangtua dengan hasil skala kategori "cukup" dan "baik" menunjukkan bahwa orangtua mampu melaksanakan fungsinya sebagai pendidik utama untuk stimulasi dini sensori anak, hal ini pun merupakan indikasi pendidikan berbasis keluarga berhasil dilaksanakan (Rohmawati, 2015). Hasil penelitian tersebut diperkuat oleh Hurlock (Reswita, 2017) yang menyatakan bahwa orangtua perlu terlibat dalam perkembangan anak dan memberikan stimulasi yang tepat sesuai dengan perkembangan anaknya. Santrock dalam (Irma, Nisa, \& Sururiyah, 2019) menyatakan bahwa peran orangtua memiliki andil dalam memberikan pengarahan dalam proses belajar anak seperti pengembangan dan peminatan diri anak. Pernyataan tersebut pun selaras dengan 
DOI: 10.31004/obsesi.v5i1.741

pendapat (Ardiyana, Akbar, \& Karnadi, 2019) bahwa keterlibatan orangtua dalam melakukan stimulasi dini memiliki peran penting dalam keberhasilan pendidikan anak. Keseluruhan pernyataan di atas diperkuat dari hasil penelitian (Sandi \& Setyorini, 2018) yang menyatakan bahwa orangtua memiliki kesempatan emas untuk mendidik anaknya di usia dini karena pada fase ini anak masih mudah dituntun dan dibentuk.

Berdasarkan hasil dari penelitian survei ini pun dapat dilihat bahwa tidak ada responden guru Satuan Paud Sejenis dalam hal ini guru satuan Pos Paud maupun orangtua yang masuk dalam kategori "kurang". Pemahaman dan keterampilan stimulasi merupakan fondasi penting dalam proses tumbuh kembang anak, maka dari itu kemampuan guru pos Paud dan orangtua terhadap stimulasi yang diberikan kepada anak sangatlah penting. Peran guru dan orangtua yang bekerja sama sangat berpengaruh pada pertumbuhan dan perkembangan anak. Hal ini sesuai pernyataan dalam penelitian (Islamiyati, 2018) yang menyatakan bahwa pendidikan anak adalah tanggung jawab bersama keluarga, sekolah, dan masyarakat. Dalam hal ini peran guru dan orangtua menjadi unsur keberhasilan stimulasi dini sensori anak. Pemberian stimulasi dini yang sesuai dengan tahapan usia anak akan mengembangkan potensi dan meningkatkan kemampuan anak pada masa dewasa. kemampuan guru Pos Paud dan orangtua akan berpengaruh pula pada stimulasi yang diberikan untuk anak, sejauh mana mereka memahami stimulasi yang harus diberikan.

\section{SIMPULAN}

Kemampuan guru Pos Paud dan orangtua di Kecamatan Bekasi Utara terhadap stimulasi dini sensori anak berbasis aktivitas bermain dengan panca indera pada anak kelompok usia 4-6 tahun dinyatakan pada kategori "baik". Responden dalam penelitian ini sudah memahami pentingnya memberikan stimulasi kepada anak dalam proses tumbuh kembangnya. Dari hasil penelitian ini pun, $64 \%$ orangtua memiliki pengetahuan dan keterampilan yang baik terhadap layanan stimulasi dini sensori pada anak usia 4-6 tahun.

\section{UCAPAN TERIMA KASIH}

Penulis mengucapkan terima kasih kepada seluruh responden di salah satu pos paud di kecamatan Bekasi Utara dan kepada seluruh pihak yang membantu terpenuhinya penulisan artikel ini.

\section{DAFTAR PUSTAKA}

Andriani, D. (2017). Kiat Menghadapi Anak dengan Gangguan Sensori. Tempo, Retrieved from Https://Cantiktempo.Co/Read/858285/Kiat-MenghadapiAnak-Dengan-GangguanSensori/FullEview $=$ ok.

Ardiyana, R. D., Akbar, Z., \& Karnadi, K. (2019). Pengaruh Keterlibatan Orang Tua dan Motivasi Intrinsik dengan Kepercayaan Diri Anak Usia Dini. Jurnal Obsesi: Jurnal Pendidikan Anak Usia Dini, 3(2), 494. https:/ / doi.org/10.31004/obsesi.v3i2.253

Astuti, W., Adiba, F., \& Muna, N. (2017). Model Keterlibatan Orangtua dalam Optimalisasi Program Stimulasi Motorik Kasar, 483-494.

Darnis, S. (2018). Aplikasi Montessori Dalam Pembelajaran Membaca, Menulis Dan Berhitung Tingkat Permulaan Bagi Anak Usia Dini. Jurnal Caksana: Pendidikan Anak Usia Dini, 1(01). https://doi.org/10.31326/jcpaud.v1i01.3

Haryanti, D., Ashom, K., \& Aeni, Q. (2019). Gambaran Perilaku Orang Tua Dalam Stimulasi Pada Anak Yang Mengalami Keterlambatan Perkembangan Usia 0-6 Tahun. Jurnal Keperawatan Jiwa, 6(2), 64. https:/ / doi.org/10.26714/jkj.6.2.2018.64-70

Hasanah, N., \& Sugito, S. (2020). Analisis Pola Asuh Orang Tua terhadap Keterlambatan Bicara pada Anak Usia Dini. Jurnal Obsesi: Jurnal Pendidikan Anak Usia Dini, 4(2), 913. https://doi.org/10.31004/obsesi.v4i2.456

Hewi, L., \& Asnawati, L. (2020). Strategi Pendidik Anak Usia Dini Era Covid-19 dalam 
Menumbuhkan Kemampuan Berfikir Logis. Jurnal Obsesi : Jurnal Pendidikan Anak Usia Dini, 5(1), 158. https:// doi.org/10.31004/obsesi.v5i1.530

Husain, R., \& Kaharu, A. (2020). Menghadapi Era Abad 21: Tantangan Guru Pendidikan Anak Usia Dini di Kabupaten Bone Bolango. Jurnal Obsesi : Jurnal Pendidikan Anak Usia Dini, 5(1), 85. https:// doi.org/10.31004/obsesi.v5i1.527

Irma, C. N., Nisa, K., \& Sururiyah, S. K. (2019). Keterlibatan Orang Tua dalam Pendidikan Anak Usia Dini di TK Masyithoh 1 Purworejo. Jurnal Obsesi: Jurnal Pendidikan Anak Usia Dini, 3(1), 214. https:// doi.org/10.31004/obsesi.v3i1.152

Islamiyati. (2018). Hubungan Kerjasama Orangtua Dengan Perkembangan Anak Usia Dini di Kelompok Bermain. Jurnal Pendidikan Anak Usia Dini, 12(1), 66-76. https:// doi.org/10.21009/JPUD.121 06

Jumilah, Efastri, S. M., \& Fadillah, S. (2018). Upaya Meningkatkan Kreativitas Anak melalui Permainan Finger Painting Usia 5-6 Tahun di TK Harapan Bunda Pekanbaru. Paud Lectura, 2(1), 31-39. https://doi.org/10.31849/paudlectura.v2i01.1989

Lubis, M. Y. (2019). Mengembangkan Sosial Emosional Anak Usia Dini Melalui Bermain. Generasi Emas: Jurnal Pendidikan Islam Anak Usia Dini, 2(1). https:/ / doi.org/10.25299/ge.2019.vol2(1).3301

Meggit, C. (2018). Memahami Perkembangan Anak (pertama). Jakarta: PT Index.

Mufarizuddin, M. (2017). Peningkatan Kecerdasan Logika Matematika Anak melalui Bermain Kartu Angka Kelompok B di TK Pembina Bangkinang Kota., 148-155.

Niken, G. (2016). Waspada, Ini Tanda Anak Mengalami Gangguan Sensorik.

Pratiwi, H. (2020). Screen Time dalam Perilaku Pengasuhan Gererasi Alpha pada Masa Tanggap Darurat Covid-19. Jurnal Obsesi : Jurnal Pendidikan Anak Usia Dini, 5(1), 265. https:// doi.org/10.31004/obsesi.v5i1.544

Putri, V. A., Sofia, A., \& Utaminingsih, D. (2017). Bermain Sensorimotor Meningkatkan Kreativitas Anak Usia Dini. Jurnal Pendidikan Anak, 3(1).

Reswita. (2017). Hubungan Pola Asuh Orangtua dengan Capaian Perkembangan Anak. PAUD Lectura: Jurnal Pendidikan Anak Usia Dini, 1(1), 72-81. https:/ / doi.org/10.31849/paudlectura.v1i1.506

Rohmawati, A. (2015). Efektivitas Pembelajaran. Jurnal Pendidikan Usia Dini, 9(1), 15-32. https:// doi.org/10.21009/JPUD.091.02

Roza, D., Nurhafizah, N., \& Yaswinda, Y. (2019). Urgensi Profesionalisme Guru Pendidikan Anak Usia Dini dalam Penyelenggaraan Perlindungan Anak. Jurnal Obsesi : Jurnal Pendidikan Anak Usia Dini, 4(1), 277. https:/ / doi.org/10.31004/obsesi.v4i1.325

Saipudin, A. (2010). Problematika Pendidikan Anak Usia Dini Di Indonesia. Cakrawala Dini Jurnal Pendidikan Anak Usia Dini, 4(1). https:/ / doi.org/10.17509/cd.v4i1.10371409

Sandi, N. V., \& Setyorini, R. (2018). Analisis Kegiatan Bimbingan Belajar pada Anak Usia Dini dalam Kreativitas Pembelajaran. Jurnal Pendidikan Islam Anak Usia Dini, 01(02). https:// doi.org/10.25299/ge.2018.vol1(2).2749

Sasi, D. N., \& Syafrudin, U. (2019). Meningkatkan Pemahaman Orangtua dan Guru tentang Hakikat Pendidikan Anak Usia Dini melalui Kegiatan Seminar Pendidikan. Paud Lectura, 3(2), 1-9. https:// doi.org/10.35896/ijecie.v3i2.80

Yulianto, D., Lestariningrum, A., \& Utomo, B. H. (2016). Analisis Pembelajaran Holistik Integratif Pada Anak Di Taman Kanak-Kanak Negeri Pembina Grogol Kabupaten Kediri. JPUD - Jurnal Pendidikan Usia Dini, 10(2), 277-294. https:// doi.org/10.21009/jpud.102.05

Zmigrod, S., Colzato, L. ., \& Hommel, B. (2015). Stimulating Creatiity: Modulation of Convergent and Divergent Thinking by Transcranial Direct Current Stimulation (TDCS). Creativity Research Journal, 27(4), 353-360. https:// doi.org/10.1080/10400419.2015.1087280 